\title{
Public participation in services delivery projects in Buikwe District Local Government Uganda
}

\section{Commonwealth Journal of Local Governance}

Issue 18: December 2015

http://epress.lib.uts.edu.au/ojs/index.php/cjlg

\section{Sylvester Kugonza}

Uganda Management Institute (UMI)

Kampala, Uganda

Email: kamanyire_kugonzas@yahoo.co.uk

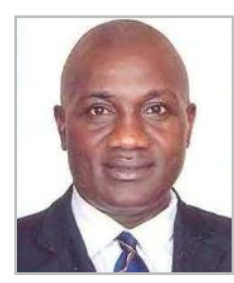

\section{Robert Mukobi}

Secretariat for Accountability Sector

Ministry of Finance, Planning and Economic Development

Kampala, Uganda

Email.mukrobb@gmail.com

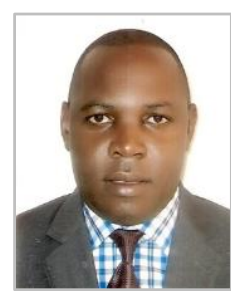

\begin{abstract}
Public participation as a democratic right has gained wide acceptance in local governance, both to improve accountability in service delivery and to enhance civic consciousness. Uganda now has two decades' experience of various forms of decentralisation. However, the extent of public participation both in local planning and in holding local politicians to account has been inconsistent. Taking Buikwe District local government as a case study, the authors argued that three key factors influence public participation in local governance - access to information, ability to use information effectively, and awareness of citizens' rights, roles and responsibilities. They found that these factors positively influenced overall respondents' participation in local government projects by $10.2 \%, 19 \%$ and $22 \%$ respectively based on Pearson Correlation Coefficient. The study further found that information is not readily accessible or effectively disseminated to the majority of citizens and therefore is not fully harnessed for planning, monitoring and evaluating government projects. Reasons for this inadequate access included: limited and costly infrastructure for handling information: lack of skills in relation to how and when to use information; and lack of analytical and simplification skills among those disseminating information. In light of these findings, the paper recommends that information dissemination must be planned and carried out in a targeted and systematic way, if citizens' awareness of their rights, roles and responsibilities in service delivery is to be achieved.
\end{abstract}

Keywords: Participation, service delivery projects, information sharing, accountability, Uganda

\section{Introduction}

Since 1986, Uganda's governance system has been described both as a 'democratic surge' and the 'beacon of Africa', but also as a 'democratic recession' (Mwenda 2007; World Bank 2000, Diamond 2008). The first two descriptions can be attributed to the era before 2001, and the latter applied to the last ten years. Paradoxically, the period since 2001 coincides with one of the largest expansions in

(c) 2015 Sylvester Kugonza and Robert Mukobi. This is an Open Access article distributed under the terms of the Creative Commons Attribution 4.0 Unported (CC BY 4.0) License (https://creativecommons.org/licenses/by/4.0/), allowing third parties to copy and redistribute the material in any medium or format and to remix, transform, and build upon the material for any purpose, even commercially, provided the original work is properly cited and states its license. 
number of local governments in the world within a single country. On average six local governments have been created per year in Uganda since 2008, with two main objectives: 1) to bring services nearer to the people through increased participation; and 2) to secure democratic control by local citizens of those local governments.

Participation, transparency and accountability are widely acknowledged to be key pillars of good governance. It could therefore be inferred that prolific creation of local governments in Uganda will have enhanced not only service delivery, but also participation. This paper asks the question: Has it?

This paper reports on an empirical study of factors affecting public participation in service delivery projects in Buikwe District Local Government (BDLG), Uganda. It first sets out the contextual background to the issues, explains the study methodology and links theory from literature to the actual practice of participation in BDLG. It then reports its research findings:

i) it assesses how access to information affects public participation;

ii) it examines how the ability to effectively use information influences public participation;

iii) it scrutinises the extent to which citizens' awareness of participation as a right affects their involvement.

Lastly, recommendations for encouraging more effective participation in service delivery projects in local governments are proposed.

\section{Contextual background}

Modern efforts towards decentralisation in Uganda began with the enactment of the Resistance Councils and Committee Statute 1987, which had two broad aims: to transform district councils into corporate bodies with responsibility for service provision, and to delegate broad policy-making and planning powers to local councils. The 1993 Local Government (Resistance Councils) Statute (LGS) and the 1997 Local Government Act (LGA) further strengthened districts by devolving more planning powers, which in theory meant that they ceased to be de jure arms of central government. These institutional reforms were further bolstered by the promulgation of the constitution of 1995 (in between the LGS 1993 and LGA 1997), which enshrined citizens' participation in planning and governance of the country. Within the section on National Objectives, the constitution states:

The State shall be based on democratic principles, which empower and encourage the active participation of all citizens at all levels in their own governance... The State shall be guided by the principle of decentralization and devolution of governmental functions and powers to the people at appropriate levels where they can best manage and direct their own affairs.

The constitution further prescribes the creation of a National Planning Authority (NPA) in Section 125; and the LGA 1997 in Section 36 stipulates a counterpart institution at sub-national level, such as 
a district council, to discharge the planning functions of NPA as devolved. The LGA 1997 also stipulates the creation of district technical planning committees chaired by the district's chief administrative officer. The law mandates district councils (in their role as a local planning authority) to prepare comprehensive and integrated development plans, incorporating proposals of lower-level local governments, for submission to the NPA. Formally, all projects are identified and developed as part of this national and local government planning process. The public policy reforms that ushered in these changes aimed at enhancing the right to participation, which was then enacted within the Access to Information Act 2005. This Act gave effect to the constitutional guarantees of access to government information.

BDLG, the focus of this paper, is one of the 112 district local governments of Uganda empowered by the LGA as an autonomous entity. However, despite implementing initiatives to enhance public participation as outlined under the reforms, participation in government projects and community ownership of them is still low - as the Buikwe District development plan for 2010-13 observes (Buikwe District Local Government 2010).

\section{Theorising and justifying local participation}

The rationale for participative government at local level stems from a recognition that involving people in governing processes makes local authorities accountable to citizens for services and development in their area (Blair 2000; Sirker and Cosic 2007). An ancillary benefit is that the work of the authorities becomes transparent to local people, as they are involved in all activities (Holdar and Zakharchenko 2002; Manowong and Ogunlana 2006).

Scholarly thought (e.g. Stone 1989) and the work of practitioners was reflected in 'Agenda 21', the outcome document of the 1992 United Nations 'Earth Summit' in Rio de Janeiro, Brazil, which highlighted stakeholder participation as a major factor in promoting sustainable development. Since then, Agenda 21 has been given political, legal and regulatory force by national governments and by United Nations organisations in every area of human endeavour. The involvement of stakeholders ('participation') has now become a standard condition for approval or funding of many development projects. In some jurisdictions, the right to public participation has been enshrined in law, conceived as a human right or as a manifestation of the right to freedom of association and assembly. Countries such as the Netherlands, Germany, Denmark, the USA and Sweden - and also Uganda - have public participation and freedom of information provisions in their legal systems (Zillman et al. 2002).

\section{Model of participation}

Public participation in development projects may be grounded in one or more of several theories and models. This study uses the Mathbor (2008) model of effective community participation. This model 
assumes that communities begin their dialogue when a development intervention is first discussed, and continue to work together until successes and failures of the project are fully evaluated and reintegrated into future planning. This process is depicted in Figure 1 below.

According to Mathbor (2008), community participation undergoes four stages:

1) Involvement: this includes information, education and planning (IEP) to provide adequate and timely evidence, educate people about the development initiative, and outline a plan of action.

2) Control: this encompasses implementation, co-ordination and monitoring (ICM). In this stage it is assumed that once local people are well informed about a particular development initiative, they are in a better position to plan on their own and implement project activities.

3) Ownership: this stage assumes that local people share project costs - if not by contributing money, then in kind by offering time, materials or other efforts. This sharing of costs is assumed to engender a sense of ownership and commitment to the project.

4) Feedback: this stage includes consultation to harness local people's knowledge and experience, reassess their needs and evaluate outcomes of a development project. It also holds local people accountable for successes and failures.

Figure 1: An Effective Community Participation Model for Development Projects Source: Mathbor (2008)

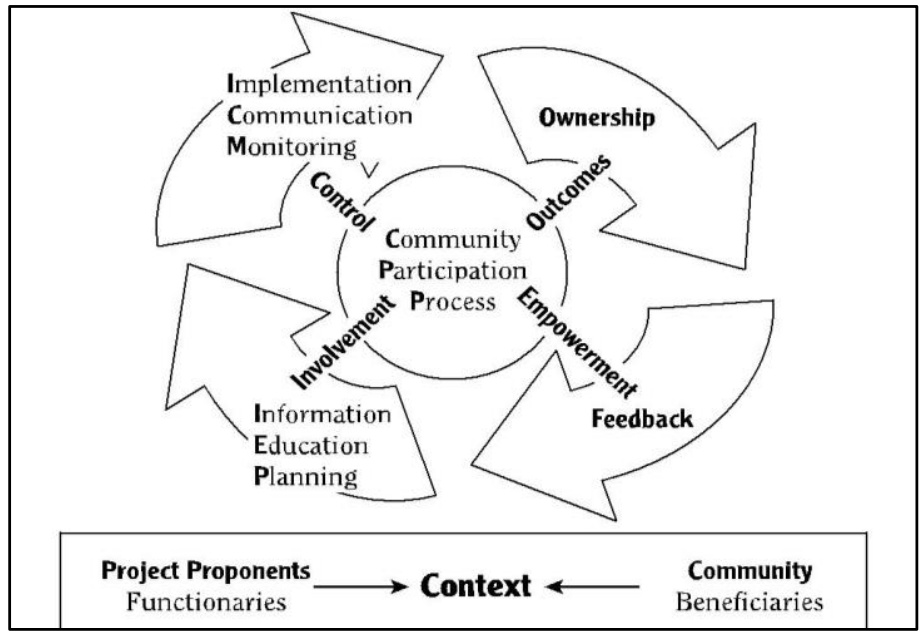

In this model, therefore, community participation in development projects is hypothesised to be effective by involving local people in all stages. Mathbor (2008) contends that each stage is the result of a set of elements that emerges from the views, opinions, and perspectives of the stakeholders. Further, although elements in the model are seen as different stages, in practice they are often interrelated and interwoven (Mathbor 2008). The model further assumes that community participation is a key tool for collecting indigenous knowledge and promoting social change in communities. 


\section{Analytical framework}

The Mathbor model provided the basis for the analytical framework used by this study, as indicated in Figure 2. It was conceptualised that accessibility and utilisation of information, and awareness of citizens' rights, roles and responsibilities would be the independent variables which would influence public participation (the dependent variable) in local government projects. 'Participation' for the purposes of this study is defined as involvement in planning and public demand for accountability, including monitoring and evaluation (DeSario and Langton 1987; Malena 2009).

\section{Figure 2: Analytical Framework}

Source: Authors, with insights from Khwaja (2004) and Kugonza (2011)

Independent Variables

Information Accessibility

Information Utilisation

Citizens' awareness of participation as a human right
Dependent Variables

Participation

Planning

Public demand for accountability

\section{Access, utilisation and right to information for participation}

Effective access to meaningful information is the first step in empowering citizens to exercise control over resources and institutions (Schwarte 2008). In his address to the World Bank conference 'Global Knowledge' in 1997, Kofi Annan, the then Secretary-General of the United Nations, observed that the great democratising power of information had given Africa a chance to effect change and alleviate poverty in new ways.

Access to information enables citizens to articulate their voice, monitor effectively, hold government accountable and enter into informed dialogue about decisions which affect their lives. Information empowers all citizens, including vulnerable and excluded people, to claim their broader rights and entitlements. Only informed citizens can stand up for their rights and hold public officials accountable for their actions and decisions (Chege et al. 2008).

However, access to information and technology will not in itself create more informed citizens without an understanding of and capacity to use the information effectively. Tise (2009) points out that while the global information explosion has made information literacy skills essential if people and nations are to fully harness this information, in many countries there are real structural and political barriers to doing so. These obstacles affect both the capacity of citizens to realise their right to information and to participate, demand better governance and ultimately better services, and the incentives for them to do so (Pejova 2002). Lack of information literacy skills and failure to use information effectively wastes resources and affects productivity in all spheres of life and work. For 
development initiatives to gain ground, beneficiaries must first be aware of their rights, roles and responsibilities (Mohammad 2010). But there is more to it than that: devolution can only be successful if citizens are also aware of the channels through which they can exercise these rights (Omolo 2010).

\section{Research methodology}

This research adopted a cross-sectional design and used mixed methods, nesting quantitative methods into an overall qualitative approach. A sample of 291 respondents was chosen using the statistical table used by Krejcie and Morgan (1970). The respondents at household level were selected using multi-stage simple random sampling techniques from three sub-counties of BDLG: namely Ssi, Wakisi and Ngogwe. Purposive sampling was used to select 14 key informants: five district officials, three non-governmental organisation (NGO) officials, three sub-county chiefs and three local council officials (as summarised in Table 1) who were interviewed. In addition, three focus group discussions were conducted in the three sub counties of Wakisi, Ssi and Ngogwe.

Table 1: Summary of Study Population

\begin{tabular}{|l|c|c|c|l|}
\hline Population Category & Population & Sample Size & Percentage & Sampling \\
\hline Household heads & 1,124 & 291 & 26 & Multi-stage random \\
\hline District officials & 5 & 5 & 100 & Purposive \\
\hline Sub-county officials & 3 & 3 & 100 & Purposive \\
\hline NGO officials & 3 & 3 & 100 & Purposive \\
\hline Local council officials & 3 & 3 & 100 & Purposive \\
\hline
\end{tabular}

Data obtained from household heads (using probability sampling) was analysed using the Statistical Package for the Social Sciences (SPSS). Relationships between variables were measured using the Pearson correlation coefficient and tested using regression analysis and analysis of variance (ANOVA) at a 5\% level of significance. Qualitative data was categorised and themes developed in accordance with the objectives of the study.

\section{Findings and discussion}

\section{How information accessibility affects public participation in local government}

The majority of respondents $(62.5 \%)$ disagreed with the view that full information on government projects (schools, health facilities etc) is available and accessible to community members. Of the remainder, 5.8\% were unsure and $31.7 \%$ felt that such information is available. Findings from focus groups indicated that people's involvement in development projects is impeded by inadequate information. Participants observed that community members are hardly able to access information on service delivery, or for planning and monitoring government projects and programmes:

Leaders have been arguing for us to get involved in government projects in this community but we don't know where to begin. You cannot know which school needs to be 
constructed, when and where, or when drugs are brought to Ngogwe Health Centre. The little information comes late, especially when everything has been completed, and we hear it like rumours. Focus group participant, Ngogwe sub-county

In another focus group a similar situation was reported:

Accessibility of information in our community is so poor so we don't get involved in most of these government initiatives like NAADS, construction projects etc. It is always during burial ceremonies or funeral rites that those politicians begin telling people that there are new projects in the community, [and] arguing [for] people to participate; they don't tell us the details of such projects. Focus group participant, Wakisi sub-county

Some areas were found to lack structures to support access to information on development projects. For instance, some community members mentioned that local councils were no longer effective on issues concerning service delivery and, in most cases, had no staff member responsible for information dissemination. Interviews with district officials similarly revealed that there was inadequate budget provision at sub-county and district levels to raise public awareness and disseminate information to communities.

It was also claimed that a few people have access to some information, mostly friends and relatives of district officials, or those willing to bribe them. This was especially the case for contracts. In Ssi one participant explained:

What I have observed is that central government is doing the best to improve the welfare of the people but officials at the district don't deliver the information to the local people: eg when there is money for tendering roads, information for bidding reaches only a few people, especially those known to the district officials or those willing to bribe, thus leaving many of us not involved in the development projects. Focus group participant, Ssi sub-county

The study also included questions on the procedures and channels for obtaining information in the community. The majority of respondents $(58 \%)$ said such procedures and channels were not clear or known to them, while $18.9 \%$ were unsure of their existence and only $23.1 \%$ felt knowledgeable about such procedures and channels. In two focus groups - in Ssi and Ngogwe sub-counties - participants were unaware of any formal process and mechanism for obtaining the information required to plan and evaluate projects.

On the question of information dissemination, $55.3 \%$ of respondents said information for planning and assessing performance was not regularly disseminated by either the government or other stakeholders to the general public. Of the remainder, $25.4 \%$ were not sure while only $19.3 \%$ agreed that it was regularly disseminated.

On methods of information dissemination, the majority of respondents (63.6\%) agreed that publicity channels included local radio stations, FM radio stations, newspapers and noticeboards. However, 
$22 \%$ disagreed, and were not aware of these, and $4.5 \%$ were not sure how information was publicised. As one focus group participant pointed out:

There is awareness creation in the meeting for bulungi bwansi [unpaid community work] from Buganda Kingdom and the need to fight malaria. Sometimes we obtain information through churches, Central Broadcasting Service (CBS) radio Buganda, Baba FM, [and] newspapers among others. Occasionally, information is pinned on the noticeboards at the sub-county headquarters; sometimes our local council's leaders give us information during community meetings. Focus group participant, Ngogwe sub-county

Field observations revealed that some tools used to inform people were either absent or not appropriately used. For instance, there was no noticeboard at the Buikwe district headquarters. At the headquarters of Ssi and Ngogwe sub-counties, noticeboards were positioned outside office premises, and thus susceptible to rain damage. FGD participants also mentioned that there was not continuous updating of information on the noticeboards, so old information was kept for several months.

Additionally, the majority of respondents (62.6\%) felt that limited capacity and infrastructure such as computers and internet connections affected access to the information required for planning and ensuring accountability. Qualitative findings from the focus groups were similar; participants highlighted a lack of basic technical equipment and communication systems such as computers and internet connections within communities. Many participants were unaware of government websites and their functions. Nor was there any library or community resource centre where people could access vital information to use for planning and monitoring government projects. As one participant observed:

They tell us that we can get information on the internet but some of us have never seen it, we don't have computers in our community and we don't know how to use them because we have not been trained, and even electricity is only in our neighbouring parish. Focus group participant, Ssi sub-county

Researchers also asked respondents about the Access to Information Act 2005. Over half (56.7\%) of respondents felt the Access to Information Act 2005 was not known by or accessible to community members, while another $29.2 \%$ were not sure of its existence. On coding and content of information nearly half $(44 \%)$ of respondents disagreed with the view that the Access to Information Act 2005 was clear and easily understood. Another $37.7 \%$ were unsure - probably because they had never seen the Act. It seems clear that that many participants had never seen or even heard of the Access to Information Act 2005, and thus could not use it to request for information that would be useful to them for planning projects or holding service providers to account. This finding was borne out by interviews with district officials. As one observed:

Officials from [the] Prime Minister's office visited the district [on awareness creation exercise for all] but [in the end] sensitised only the District Information Officer and Chief Administrative Officer about the Access to Information Act 2005. Some of us were 
left out and up to now there has been no attempt to sensitise the people about the Act. District Planner, BDLG

The study also revealed a widespread view that there is a lack of transparency and openness when it comes to making information available to the community. The majority of respondents (63.2\%) mentioned that some information, such as district work plans, details of funds released from the central government and bills of quantities for construction works, are still treated as confidential.

Specifically, $68.3 \%$ of respondents said they could not access information such as LG work plans, budgets, or details of central government financial releases. Additionally, respondents pointed out that details of the tender processes are often inaccessible to the public. Seventy-six per cent of respondents did not even know the procedures for obtaining such information, while those who did know them claimed that the information was not provided in a timely manner, and that the cost of obtaining it was quite unreasonable.

The study then looked at associations between information accessibility and public participation. Its findings indicate that lack of availability of meaningful information has a significant effect on community participation in projects; for example, $60.5 \%$ of respondents said they could not participate in monitoring and evaluation because they lacked any meaningful information to start from. To establish the relationship between information accessibility and public participation, the aggregated index of information accessibility (extent to which respondents said information was readily accessible) and overall aggregated index of public participation (extent to which they had participated in projects) were correlated using Pearson Product Coefficient. The result showed that information accessibility accounts for $10.2 \%$ of variation in public participation. This finding implies that making information available to the public and propping up mechanisms to access it increases participation in planning and in holding service providers to account. This confirms hypothesis 1 of the study, namely:

Hypothesis 1: There is a positive relationship between information accessibility and participation in lower LG projects.

These findings support both Daruwala and Nayak (2007) and UNDP (2003), which both found that access to accurate, clear and relevant information enables disadvantaged people to influence issues that are critical to their lives through claiming basic rights and entitlements, availability of basic services, work opportunities etc. It also helps them to understand government policies and programmes, how participation and decision-making work, their role in these processes and how to effectively monitor and hold government to account. 
A related study by Holdar and Zakharchenko (2002), adds that in order to have effective citizen participation, the information disseminated has to be relevant. This information should come from both the general public and the government, and without information effective citizen participation is virtually unattainable. Similarly, Bastidas (2004) and UN Habitat (2003) contend that free access to information plays an important role in promoting transparency, participation and good governance. They spell out that for it to be meaningful information must be relevant, provided in a timely manner, and with its source clearly evident. They also note that the cost to citizens of obtaining the information should be reasonable, and that it should be available across social class boundaries.

\section{How information utilisation affects public participation in local government projects}

In this study nearly half $(47.7 \%)$ of respondents agreed that they didn't know how to use available information for the planning, monitoring and evaluation of government projects, $21.3 \%$ were not sure and only $31 \%$ said they knew how to use such information. Similarly, about half of respondents (49.4\%) cited complicated and costly infrastructure and technology as a hindrance. Similar views were found in the focus groups, where participants pointed out that they lack access to information sources such as public libraries, internet cafes, telecentres, workplace information centres and conferences, and therefore cannot use information available through these channels.

Turning to the content of information, 57.7\% agreed that financial releases, district plans and other district documents are complex and difficult to use. A further $19.6 \%$ were not sure, although $22.7 \%$ disagreed and felt the information content was not too complex. The study did find that $81 \%$ of respondents were literate, but nevertheless the majority of respondents (65.3\%) said the coding (language) in which the information is disseminated is difficult, with just $26.5 \%$ saying it was not difficult. District officials interviewed also noted that the terms used in, for instance, financial releases are too technical for local people to understand as they contain public service jargon, acronyms and abbreviations without explanation. The same situation prevailed even on public noticeboards.

Lack of information literacy skills was also found to affect information utilisation. Most respondents (73.1\%) said they lacked the capacity and skills to utilise information for planning and monitoring development projects in their area, and only $21 \%$ felt they had such capacity and skills. Only $32.7 \%$ of respondents had been trained in how to use information to enhance participation in service delivery. Focus group participants observed sometimes they are not even aware of the need for information, and also find difficulties accessing, manipulating, and creating meaning from information to explain service delivery to their community.

District Officials noted that many official standards must be met at district level (e.g. the provisions of the Decentralisation Act, the local clients' charter, the Constitution of Uganda and other legislation, 
the district development plan, and sub-county development plans); however most such documents lack popular versions which can be used by members of communities with ease.

Further investigation revealed that $73.2 \%$ of respondents agreed that failure to utilise available information well had negatively affected service delivery in their community. Community members pointed out that had they utilised effectively available information, they could have held private service providers and public officials at the district and sub-county levels accountable; and could also have influenced decisions pertaining to service delivery more. These findings supported hypothesis 2 , namely:

Hypothesis 2: Information utilisation positively affects public participation in local government projects.

In this study information utilisation appeared to have significant influence on public participation. An increase in information utilisation is associated with increased public participation in planning, monitoring and assessing government projects. Similar studies (Ansari 2008; Chege et al. 2008) also found that people who have access to information and understand how to use it to exercise their political, economic and legal rights become empowered, which in turn enables them to build their strengths and assets and improve their quality of life. This bears out the argument by Mukungu (2011) that 21 st century society requires access to and use of information for its decision-making, growth and development.

It became clear in this study that community members and government officials both value participation; however the ability to effectively utilise information - especially for the former group is constrained by lack of information literacy, analytical skills, and for the latter, ability to simplify messages. For example, it was noted that the practice of putting information about central government releases of funding and budget performance on noticeboards at sub-counties and district headquarters was ineffective, as it had not spurred people to seek further information and increase their participation to secure better service delivery. The same was corroborated by reports and records held in sub county and district offices.

An important finding was that information in the community was supplied, as opposed to being demand-driven, and rural people are seldom able to contact those who supplied information to understand their intentions. Some community members believed the government programmes in their area had nothing to do with them, so did not believe they should bother to get involved. Others felt they did not have the capacity to understand and harness information to engage with service providers to achieve better services. It is important that service providers and government officials be aware of these barriers, rather than developing mistrust and being frustrated by community indifference. 
These findings bear out the work of Herranz (2010), who suggests that the potential for access to information to improve governance lies in the willingness of government to be transparent as well as in the ability of citizens to demand and use information. Both these aspects may be constrained in low-capacity settings. Pande (2008) posits that citizens' and civil society organisations (CSOs) often lack the skills and knowledge to process, analyse or use complex information. They may also have limited capacity to conduct advocacy and to develop the networks and platforms that are needed in order to ensure the concerns of their constituencies are heard.

Another important finding of the study was that community members are sceptical about the objectives of government programmes, and therefore reluctant to get involved in another round of 'broken promises'. This cynicism appears to flow from a presumption that public officers are corrupt and dishonest, so whatever information they provide will be incorrect and/or insufficient, and not fit for purpose. Sub-county and district officials were also found to be reluctant or sometimes not interested in involving local people, perhaps because there might indeed be a tendency towards corruption. Evidence suggests that in Uganda, where demands for accountability and transparency are ignored, there might be a syndicate composed of allied sub-county and district officials as well as elected leaders. These findings are also supported by Uganda's $2^{\text {nd }}$ Public Procurement Integrity Survey (Public Procurement and Disposal of Public Asset Authority 2011), which attributed poor public participation in government projects to apathy.

To sum up this section, a significant proportion (47.7\%) of people in Buikwe District did not know how to use available information for planning, monitoring, evaluation and ensuring accountability by service providers. Factors preventing them from doing so included limited and costly infrastructure and technology, which is required to access and utilise information. Additionally, $73.1 \%$ of respondents believed that inadequate information literacy skills were also a hindrance, with a significant impact on public participation: $73.2 \%$ of respondents agreed that failure to utilise available information well had negatively affected services in their community.

\section{Public awareness of the right to participation as a human right}

In line with a report by the Inspectorate of Government (2008), the Uganda National Integrity Survey (NIS) this study documented a lack of awareness of rights by the general public - for example the right to the protection of public property, to ensuring proper use of public utilities, and to access to public utilities, among others. Due to limited awareness of these rights, public property and utilities have been abused more or less with impunity, as there is little chance that anyone in the community will report such crimes even when detected. For example, the central government's 'Community Needs Assessment and Baseline on Baraza report' (Office of the Prime Minister 2012) found that 9\% 
of the population is unaware of their right to demand local services that ought to be provided by government. Even the majority who were aware of their rights did not know how to exercise them.

The study also found that CSOs had supplemented media efforts in building civic competency, by mobilising and educating people about their rights and encouraging them to demand services as part of their rights. CSOs act as a conduit between government and the people, pointing out shortcomings in service delivery and stepping in to provide missing or inadequate services when government fails to respond. However, in Buikwe district as already pointed out, the impact of CSOs in creating awareness has been quite limited, due to a combination of factors ranging from limited resources to political interference.

This study's findings indicate that $26 \%$ of respondents were not aware of their rights, roles and responsibilities in local service delivery. Even among those who were aware of their rights, $50.5 \%$ did not know how to exercise them. This lack of civic competence may explain the level of apathy discussed above. These findings did not support hypothesis 3 .

Hypothesis 3: Citizens' awareness of participation as a right significantly increases their involvement in local government projects.

It would seem that awareness of participation as a human right does not per se significantly affect participation in local government projects; it is the civic competence to participate effectively that seems important. Some respondents also criticised the behaviour of government functionaries, especially security and intelligence staff, who tend to isolate individuals or groups that demand accountability or attempt to assert certain rights. As one respondent pointed out:

We may know who to question and how to voice our concerns in various ways, but you end up being labelled opposition and our people fear that. They choose to keep quiet [but it's] not because they are happy and don't know how to react to poor service delivery. Focus group participant, Ssi sub-county

Discussion with participants during focus groups indicated that some community members were conversant with the idea of participation as a right, and in principle eager to participate in planning, monitoring and holding service providers accountable. Yet this does not happen often. Why not? Interview findings revealed: of the householders surveyed, over half (50.5\%) believed that involving people in decisions about their own projects is a time-wasting and exhausting process. Similarly, $71.2 \%$ of respondents said they would not participate in planning and demanding accountability because they think nothing would change. Only $21.6 \%$ of respondents disagreed with this view; $7.2 \%$ were unsure. Focus groups told a similar story: participants revealed they had lost interest in following up government programmes because they felt the government was not concerned about their plight of crushing poverty and unemployment. 
The situation seemed to be aggravated by corruption: $78.3 \%$ of respondents reported that increased levels of corruption had hindered community participation in decision-making. Only $13.4 \%$ felt this was not an issue. Focus groups expressed specific concern over the increasing level of embezzlement and bribery in their district. They claimed that district officials collude with suppliers and contractors to deliver insufficient materials and provide sub-standard goods, and do shoddy work in the district with impunity.

The study also provided interesting insights into who should actually participate. Most of the district officials interviewed appeared satisfied that participation through representatives, rather than by all citizens, was sufficient. This view was shared by a majority of respondents (69.1\%), who also believed that it is the duty of their elected representatives to demand services on their behalf, and the people merely receive what the leaders provide. Only $23.7 \%$ thought otherwise. These views were echoed during community discussions:

We elected our representatives to represent us, we give them our views and they decide for us the projects we need in the community, so why should we do what is due for them... I think it is a waste of time. Focus group participant, Ngogwe sub-county

This general tendency towards apathy, and for citizens to abdicate their right to seek accountability, may explain why bottom-up planning has not enhanced public participation in Buikwe District. Although structures do exist for community needs prioritisation and budget preparation (village development committees, parish development committees and sub-county councils), this ideal has not been realised. Some district officials claimed that the majority of the population hardly attend meetings in their locality. It was also noted that it is mostly women who attend community gatherings to discuss development priorities and service delivery, yet their views are often disregarded by the men, who are much fewer in number but who manage the meetings. It was observed that many men spend most of their time drinking, while male youths spend their time on boda boda (commercial motorcycle transport) business, sports betting and discussing sports etc., and pay little attention to community meetings. As an assistant chief administrative officer (ACAO) pointed out:

Whenever we call a meeting at the parish or village levels to discuss issues concerning the community, mainly women attend and whatever is discussed is not taken seriously by their husbands. The youths in this district are in gambling, in sports betting, or in 'bibanda' [makeshift video halls] watching football games and other movies. Whenever we try to lure the youths into these meetings, their response is that they are tired of government lies. ACAO, Buikwe District

This level of apathy could potentially be overcome by legal means through compelling people to attend meetings and get involved in bulungi bwansi (community work). Such a law is not in existence.

As a result of this situation, the majority of respondents (79.1\%) agreed that not getting involved in planning, monitoring and assessing projects (schools, health facilities etc) was a key reason for poor 
service delivery in their community. Only $13.7 \%$ disagreed. According to the Buikwe District development plan 2010-13, lack of timely monitoring and supervision of activities means that corrective measures to remedy defects are often taken too late, leading to shoddy and unsatisfactory work in the district.

\section{Summary and conclusion}

The survey results revealed that the correlations of:

- the aggregated index of information accessibility and aggregated index of public participation was 0.102 ;

- the aggregated index of the ability to utilise information effectively and aggregated index of public participation was 0.192 ;

- and that awareness of citizens' rights, roles and responsibilities and aggregated index of public participation was 0.22 .

Therefore, all the independent variables in the survey were found to be positively correlated to the dependent variable (public participation). The multiple regression analysis confirmed the effect of the information accessibility, ability to use information effectively and awareness of citizens' rights, roles and responsibilities on public participation with the following key findings:

- information accessibility was found to cause a change in respondents' participation in local government projects by a margin of $10.2 \%$, suggesting that an increase in information accessibility may increase public participation in planning and demanding accountability;

- regression analysis disclosed that $19.2 \%$ of the variation in respondents' participation in local government projects is explained by ability of the public to utilise information effectively, thus an increase in information utilisation appears to increase public participation in planning, monitoring and assessing government projects; and

- $22 \%$ of the variation in respondents' participation in local government projects is explained by public awareness on their rights, roles and responsibilities, suggesting that people will increase their participation in local government projects if they become more aware of their rights, roles and responsibilities.

By inference, the findings of this study lend credence to the Mathbor (2008) model of effective community participation, which argues that providing adequate and timely information, educating people about proposed development initiatives and outlining a plan of action are the first stages in the process of citizen engagement in decision-making. However, the model does not anticipate how to deal with apathy, especially in situations where there is active 'gate-keeping' by government 
functionaries preventing community members from holding government to account for poor services delivery.

Participation in local service delivery is widely recognised as a way of enriching democracy, building trust, increasing transparency and accountability, and advancing fairness and justice in governance at all levels. However, its successful implementation depends on resolving a number of complex issues. Uganda's decentralisation and drive for better governance provide a good case study and an interesting one, but much more is required to be done before it can be said that this drive has achieved its goals.

\section{Recommendations}

The main reason for undertaking public participation is to make development people-centred. However, this study has identified a number of challenges to public participation in Buikwe District, including: limited access to information, inability to harness information, lack of citizens' awareness and civil competences, and lack of awareness of participation as a human right. To remedy this situation, the following recommendations are proposed.

\section{Increase information availability}

Information is essential for citizens' action. It enables people to know what is happening both around them and elsewhere in other jurisdictions, to compare actual outcomes with what was planned or pledged and to learn lessons from their own experiences and from what others have done.

There is a need for governments, both central and local, to develop community resource centres, accessible bulletin boards, paper-based or digital centres, and suggestion boxes at the district and subcounty levels to ensure a regular flow of information and feedback between community members and service providers.

\section{Develop and strengthen information infrastructure}

Information sources, resources, ICT equipment and internet connections should be established, strengthened and updated in all communities so that current and relevant information can be accessed, utilised and updated.

Government should simplify technical documents such as budgets, translate important policies into local languages, and rewrite them in popular versions. 


\section{Publicise relevant information and raise community awareness}

The government and other key development partners should develop, implement and monitor a programme to create public awareness about rights and responsibilities taking into account the information needs and interests of both men and women in all communication programmes.

The procedures and channels for accessing information, and information dissemination schedules, should be clearly and widely publicised. Information on community projects should be frequently publicised in the mass media such as local and FM radio, televisions, newspapers and noticeboards.

\section{Raise awareness of relevant legislation and other standards}

There is a need to raise awareness of standard-setting laws and documents which affect the lives of local people. Examples include the Access to Information Act 2005, the Decentralisation Act, the Constitution, clients' charters, district and sub-county development plans, central government releases of funds, bills of quantity and bids - among others. These should be simplified and translated into local languages to make them more accessible, and then made available to the general public.

\section{Train local people in information literacy skills and civil competences}

Availability of information does not necessarily lead to greater citizen participation, state accountability or state responsiveness, if the information is not properly harnessed. Therefore, the provision of information and technology to access it must be accompanied by the capacity to understand it and use it effectively. Sustained efforts must be made to equip people with computer skills through training and information literacy programmes including analytical skills.

\section{Revitalise and use local council structures}

Communities should make use of local council structures to facilitate information flows between the grass roots and the centre. Open barazas or town-hall-type meetings to discuss the performance of projects and government institutions should be instituted.

\section{Adopt and utilise ICT}

ICT should be used to reinforce traditional communication channels and supplement the mass media in publicising development information. The authors recommend that an e-government programme is initiated to digitise public domain information and make it available through websites, public libraries and other appropriate media.

\section{Promote multilingualism and information dissemination to the community}

The district, in collaboration with relevant partners, should develop freely accessible education materials translated into popular versions in widely understood languages and have them appropriately disseminated to sub-counties, parishes and villages. At the same time, key information 
resources should also be translated into local dialects. To do this, central government will need to work with sub-county and district authorities to develop localised information content in various formats, taking into account the special needs of disadvantaged groups.

\section{Make the public aware of the relevance of public participation}

Public education campaigns should be undertaken to ensure that citizens are aware of their right to participate in decision-making processes. If there is a lack of knowledge of rights, or of structures to demand and enforce them, this should be addressed. Citizens need not only an awareness of their roles and responsibilities, but also the knowledge and skills to fulfil them. This calls for capacity-building in the areas of information, analytical skills and operational competences. Information dissemination should be prompt and relevant, to spur citizens and other service users to participate.

\section{Areas for further research}

The following are proposed areas for research to strengthen the academic literature on public participation in Ugandan local government:

- An assessment of the role of public participation in service delivery - other area based cases or sector specific ones (e.g. health, education etc.) could be studied;

- The level of public demand for accountability and service delivery in Uganda;

- Comparative studies on public demand for accountability and service delivery, looking at different geographical areas and methodological approaches.

\section{References}

Ansari, M.M. (2008) Impact of right to information on development: A perspective on India's recent experiences. An invited lecture delivered at UNESCO Headquarters, Paris, France.

Bastidas, S. (2004) The role of public participation in the impact assessment of trade process. Speaker Paper for the Impact Assessment for Industrial Development. Vancouver: Canadian Institute for Environment Law and Policy.

Blair, H. (2000) Participation and accountability at the periphery: Democratic local governance in six countries. World Development, 28 (1), 21-39. doi: http://dx.doi.org/10.1016/S0305-750X(99)00109-6

Buikwe District Local Government. (2010) Buikwe District development plan 2010-13. Buikwe, Uganda.

Chege, P. Okello, M. and Oenga, I. (2008) Participatory urban planning toolkit based on the Kit ale experience: A guide to community based action planning for effective infrastructure and services delivery. Nairobi: Practical Action.

Daruwala, M. and Nayak, V. (2007) Our rights our information. Empowering people to demand rights through knowledge. New Delhi India: Commonwealth Human Rights Initiative.

DeSario, J. and Langton, S. (eds) (1987) Citizen participation in public decision making. Westport, CT: Greenwood Press.

Diamond, L. (2008) Progress and retreat in Africa: The rule of law versus the big man. Journal of Democracy, 19 (2), 138-149. doi: http://dx.doi.org/10.1353/jod.2008.0029

Government of Uganda. (2006) The Constitution of the Republic of Uganda, 1995 (as amended).

Government of Uganda. The 1993 Local Government (Resistance Councils) Statute. 
Herranz, P. (2010) Filling the governance gap in disaster risk reduction. Issue Paper on Accountability and Partnerships in DRR. Manila, The Philippines: United Nations Office for Disaster Risk Reduction (UN ISDR).

Holdar, G.G. and Zakharchenko, O. (eds) (2002) Citizen participation in central and eastern Europe: A catalyst for reform and a monitor of progress. Kyiv, Ukraine: iMedia Ltd.

Inspectorate of Government. (2008) The $3^{\text {rd }}$ national integrity survey (NIS III). EPRC.

Khwaja, A. I. (2004) Is increasing community participation always a good thing? Journal of the European Economic Association, 2 (2-3), 427-436. doi: http://dx.doi.org/10.1162/154247604323068113

Krejcie, R.V. and Morgan, D.W. (1970) Determining sample size for research activities. Educational and Psychological Measurement, 30, 607-610.

Kugonza, P.K. (2011) Outsourcing public sector construction projects: How and why actors navigate formal institutions in public construction projects in Uganda. Lambert Academic Publishing.

Malena, C. (ed) (2009) From political won't to political will: Building support for participatory governance. Sterling VA: Kumarian Press.

Manowong, E. and Ogunlana, S.O. (2006) Public hearings in Thailand's infrastructure projects: Effective participations? Engineering, Construction and Architectural Management, 13 (4), 343-363. doi: http://dx.doi.org/10.1108/09699980610680162

Mathbor, G.M. (2008) Effective community participation in coastal development. Chicago, USA: Lyceum Books Inc.

Mohammad, S.N. (2010) People's participation in development projects at grass-root level: A case study of Alampur and Jagannathpur Union Parishad. Thesis: Master of Public Policy and Governance. North South University, Bangladesh.

Mukungu, F.N. (2011) Strategies for enhancing information literacy among university graduates in Uganda. $\mathrm{PhD}$ Thesis, Makerere University.

Mwenda, A. (2007) Personalizing power in Uganda. Journal for Democracy, 18 (3). doi: http://dx.doi.org/10.1353/jod.2007.0048

Office of the Prime Minister. (2012) Community needs assessment and baseline on Baraza Report. Uganda: Government of Uganda.

Omolo, A. (2010) Policy proposals on citizen participation in devolved governance in Kenya. Nairobi: The Institute for Social Accountability.

Pande, S. (2008) The rights to information and societal accountability: The case of the Delhi PDS campaign. In: P. Houtzager, A. Joshi and A. Gurza Lavalle (eds) State reform and social accountability: Brazil, India and Mexico. IDS Bulletin Vol 38, No 6, Brighton: Institute of Development Studies.

Pejova, Z. (2002) Information literacy: an issue which requests urgent action in developing countries and countries in transition, July 2002. A White paper prepared for UNESCO, the US National Commission on Libraries and Information Science, and the National Forum on Information Literacy, for use at the Information Literacy meeting of experts, Prague, The Czech Republic.

Public Procurement and Disposal of Public Asset Authority. (2011) The $2^{\text {nd }}$ public procurement integrity survey. Government of Uganda.

Schwarte, C. (2008) Public participation and oil exploitation in Uganda. The Gatekeeper series. London: International Institute for Environment and Development.

Sirker, K. and Cosic, S. (2007) Empowering the marginalized: Case studies of social accountability initiatives in Asia. Washington, DC: World Bank Institute.

Stone, L. (1989) Cultural cross-roads of community participation in development: a case from Nepal. Human Organisation, 48 (3), 206-213. doi: http://dx.doi.org/10.17730/humo.48.3.d436524749371702

Tise, E. (2009) Access to knowledge through libraries: information services and information literacy today. Available at: http://www.ifla-deutschland.de/de/downloads/keynote_tise_suedafrika.pdf 
UN Habitat. (2003) Transparency and good urban governance. Presentation at the Workshop on Transparency and Accountability, $5^{\text {th }}$ Global Forum on Re-inventing Government. Mexico City.

United Nation Development Programme. (2003) Access to information. Oslo: Oslo Governance Centre.

World Bank. (2000) The community driven development approach in the African region: A vision of poverty reduction through empowerment. Africa Region, The World Bank.

Zillman, D.N., Lucas, A. and Pring, A. (eds) (2002) Human rights in natural resources. Oxford: Oxford University Press. 